\title{
Applicability of theory of constraint in predicting Ghanaian SMEs investment decisions
}

\author{
Michael Karikari Appiah \\ Department of Economics, \\ Universiti Malaysia Terengganu, \\ Malaysia \\ kofikarikari@yahoo.com
}

\section{Bayu Taufiq Possumah}

Department of Economics,

Universiti Malaysia Terengganu,

Malaysia

bayu@umt.edu.my

\section{Nizam Ahmat}

Department of Economics,

Universiti Malaysia Terengganu,

Malaysia

nizamabmat@umt.edu.my

\section{Nur Azura Sanusi}

Department of Economics, Universiti Malaysia Terengganu,

Malaysia

nurazura@umt.edu.my

Abstract. This study investigated dimensions of SME's constraints and decisions to Invest in the Ghanaian Oil and Gas Sector. Using a binominal regression model we analyzed primary data from 497 local SMEs. The study found that SMEs with inadequate capital, had high level of competition, had high corruption perception, lacked policy awareness, lacked adequate external credit facilities, had inadequate information, lacked managerial capabilities, lacked technological capabilities were less likely to invest in the Ghanaian oil and gas sector. Per contra, inadequate human resources capabilities, inadequate entrepreneur characteristics exerted no significant influence on SMEs decisions to invest in the Ghanaian oil and gas sector. This study has implications on oil and gas policies, investment decisions and future research. Particularly Ghanaian government is required to expedite and enforced the Local Participation in Petroleum Activities Policy under the Petroleum Regulations. This study could be replicated within other emerging economies using different models.

Received: December, 2017 1st Revision: February, 2018 Accepted: April, 2018

DOI: $10.14254 / 2071$ 8330.2018/11-2/14 
Keywords: Ghanaian SMEs, Logit model, oil and gas, perceived investment constraints

JEL Classification: D02, O16, O17, P31

\section{INTRODUCTION}

SMEs definition vary (Quartey et al., 2017; Ayyagari et al., 2011; Dalberg, 2011; Abor \& Quartey, 2010; Ghatak, 2010) across countries based on the number of employees, value of assets and annual turnover of enterprises. As postulated by International Labour Organization (ILO) (2015) micro enterprises are enterprises with up to ten employees, small enterprises as enterprises between 10 to 100 employees and medium-sized enterprises as enterprises between 100 to 250 employees. The Ghana Statistical Service (2000) defined SMEs based on number of employees, thus less than 10 for small and more than 10 for medium enterprises. Moreover, Osei et al (1993) classified SMEs as follows; enterprises with up to 5 employees micro, those between 6-9 employees as small enterprise and between 10-29 as medium enterprises.

Inspite of the tremendous contributions offer by SMEs, number of constraints continue to limit SMEs growth and expansion strive. These challenges stretch across the entire value chain of the SMEs operational areas. These constraints include; finance/credit access (Ayyagari et al., 2011; Khaled, 2012; WBG, 2015; Quartey et al., 2017; Appiah, et al. 2018), competition, (Bouazza et al., 2015; Quartey et al., 2017; Appiah, et al. 2018), entrepreneurial capabilities (Kazimoto, 2014; Abood et al., 2014, Bouazza et al., 2015) human resource capabilities (Farsi \& Toghraee, 2014; Bouazza et al., 2015), technological capabilities (Bouazza et al., 2015 Farsi \& Toghraee, 2014), managerial capabilities (Bouazza et al., 2015; Quartey et al., 2017) corruption among regulators (Abood et al., 2014; Bouazza et al., 2015), inadequate information access (Farsi \& Toghraee, 2014; Appiah), inadequate institutional support (Bouazza et al., 2015; Appiah et al., 2018). In a recent study Appiah etal. (2018) avowed that policy environment has the antidote to drastically reduce the plight of SMEs if managed appropriately. However, ineffective policy environment is an indication that SMEs challenges will continue to exacerbate the Authors cautioned.

The beginning of 2007 marked important commercial quantity oil and gas discovery in Ghana. As cited in Appiah et al. (2018) in the quest for restructuring the industry to provide productive local-content development, the government of Ghana through the Ministry of Energy and Petroleum devised the local content as well as Local Participation in Petroleum Activities Policy ('Local-content Policy'), (Ministry of Energy Ghana, 2010) as a means of optimizing oil and gas benefits and ensuring local participation in the oil and gas value chain. Hitherto, the actual participations of SMEs in the oil and gas sector are unknown. The exact constraints which impede SMEs direct participation in the Ghanaian oil and gas sector had not been explicit due to mixed results (Appiah et al., 2018). These discrepancies require new empirical study to determine the internal and external constraints including perceived and actual which affect Ghanaian SMEs investment decisions in the oil and gas sector. The paper is organized into five sections. In addition to the general introduction presented herein, the next section deals with the literature review, which is followed by methodology, discussions and conclusions. 


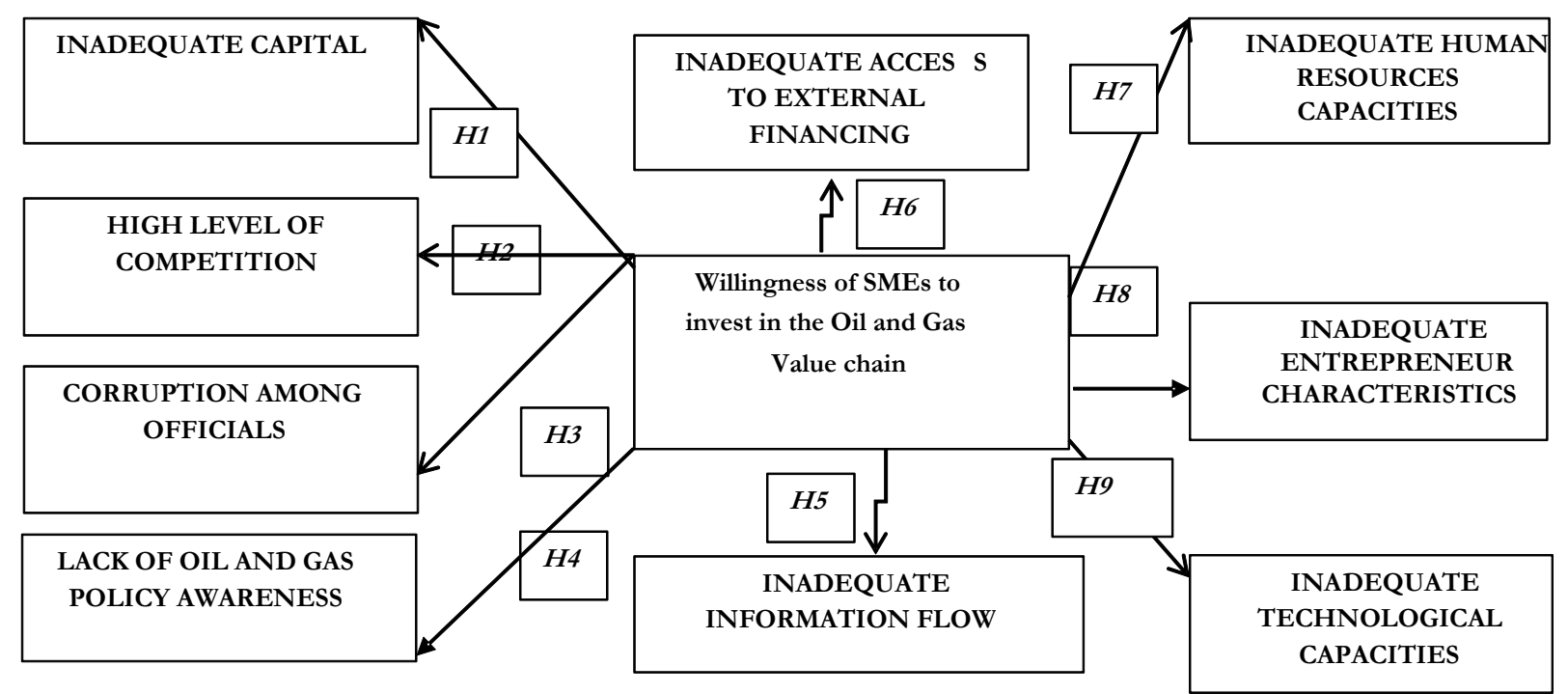

Figure 1: Theoretical Framework and Proposed Hypotheses

Source: Adopted and modified from Appiah et al. (2018)

\section{LITERATURE REVIEW}

\section{Theoretical Orientation (Theory of Constraints (TOC))}

Theory of Constraints is propounded by Goldratt (1984). The TOC utilized is utilized this study. TOC had been applied in management, economics, and supply. TOC is concerned with the feeblest rings within the supply chain to enhance systems performance. The theory proposed that firms in both production of goods or services must concentrate on comprehending their own structures regarding the processes to thrive in the international competition. Goldratt (1984) asserted that the theory could be used in production, logistics, supply chain, distribution, project management, accounting, research and development, sales and marketing. The major notion here is that each system has got at least a feeblest point, however within the body of knowledge many studies show various focus areas and disclose various cases of TOC. Thus, TOC has got many definitions from academicians and practitioners from different spheres. However, conventional point is formed for definition of almost each study constraint. Every company has the key goal to maximize profit. Therefore from this perspective, constraints are key barriers to realizing this company's goals.

Goldratt (1984) further re-echoed that anything that can contributes to thwart the process of earning higher profit is regarded as a constraint. Therefore, the ability of companies to govern constraints in their system and regulate these constraints smoothly would help them increase their profit margin. This instigates researchers to increase their investigations into all dimensions of TOC. SMEs face numerous constraints in their operations. Notable among these constraints are; finance/credit access (Ayyagari et al., 2011; WBG, 2015; Quartey et al., 2017; Appiah, et al. 2018), competition, (Bouazza et al., 2015; Quartey et al., 2017; Appiah, et al. 2018), entrepreneurial capabilities (Kazimoto, 2014; Abood et al., 2014, Bouazza et al., 2015), managerial capabilities (Bouazza et al., 2015; Quartey et al., 2017) corruption among regulators (Abood et al., 2014; Bouazza et al., 2015), inadequate information access (Farsi \& Toghraee, 2014; Appiah). The TOC is therefore employed in this study to provide fundamental understanding into constraints in the oil and gas 
industry that exert significant influence on SMEs willingness to Invest (WTI). Base on this model the framework as shown in figure 1 is proposed. Comprehensive empirical review has been presented in the next section to support the relationships.

\section{Hypotheses Development}

We present under this section review of related literature for the paper. The review had been classified into appropriate contents of SMEs constraints. These include; finance/capital/credit, information access, entrepreneurship capabilities, managerial capabilities, technological capabilities, corruption, competition, and inadequate institutional support. Of importance to this study is how each of the listed constraints affects SMEs investment decisions.

Inadequate credit facilities: Many past research studies (Ackah \& Vuvor, 2011; Lyimo, 2014; Orinda, 2014; Fuseini, 2015; Arthur, 2015; Ayevor, 2016; Taghizadeh-Hesary, 2016) reported that inadequate credit access had been a leading challenge among SMEs of all categories. In Ghana, Ayevor (2016) reported that SMEs encounter numerous difficulties when seeking funds from formal financial institutions in the country. Also, financial institutions regard small and medium-sized enterprises (SMEs) sector as too risky. Hence the financial institutions are reluctant to offer SMEs credit facilities. Again, Arthur (2015) revealed that SMEs face number of problems regarding access to credit particularly meeting the requirement of formal financial institutions despite the sector's contribution to national success. In similar vein Ackah and Vuvor (2011) reported that SMEs in the country have least chance to explore credit from some sources like Ghana Venture Capital Trust Funds, Micro-finance and Small Loans Center (MASLOC).

In Tanzania, Lyimo (2014) found that financial institution's policies and regulations must not dwell on only security but also to find more convenient manner to contain large number of SMEs to offer them credit facilities to enhance their business operations. Yoshino and Taghizadeh-Hesary (2016) reported the following as the main reasons for the retardation of SMEs growth. These are (a) absence of finance, (b) absence of appropriate databases, (c) low level of R\&D expenditures, and (d) inadequate use of information technology. The study found that SMEs have problems of higher competition, the inability to cope with ever-changing market demand, technological change and capability limitations linking to knowledge, innovation, and creativity.

Companies consider access to finance as the major hamper in the business setting, however several firms gained access following their applications. Nonetheless, the study indicated that most of the firms failed to apply for credit facility for the reason that they needed no loan and other companies attributes of the loan like sophisticated application process; unaffordable interest rates, more collateral demands and short loan maturity period seemed to be the main barriers barring the companies from accessing credit facility (Orinda, 2014; Fuseini 2015). Thus inadequate access to capital will influence SMEs investment decisions. We therefore proposed as follow,

\section{$H_{1}=$ Inadequate capital access will relate negatively to SMEs WTI}

Competition: Previous researchers (Morone \& Testa, 2005; Ruskov et al., 2012; Cant \& Wiid, 2013; Bouzza et al., 2015; Sitharam \& Hoque, 2016) emphatically reported that Competitions from within and external pose major challenge to the SMEs. Since most of the SMEs are not able to compete particularly among transnational corporations. Relatedly, Sitharam and Hoque (2016) found that competition is considered to be the key problem as the only variable among the rest that has relevant link to SMEs' performance. Furthermore, Sitharam and Hoque suggested that SMEs must get ready for indigenous and global competition further indicating that the collaboration among SMEs would be the mode for SMEs to cope with competition.

Morone and Testa (2010) examined factors affecting SMEs' competitiveness among exporting firms and reported that SMEs are not able to compete strongly. Bouzza et al. (2015) examined SMEs growth determinants and reported that major business environmental variables that influence SMEs are unfavorable 
competition from the informal sector, burdensome and expensive bureaucratic procedures, cumbersome laws, policies and regulations, inadequate tax system, absence of access to industrial real estate, lack of access to outside financing and less human resources capabilities. Furthermore, Bouzza et al. revealed that entrepreneurial attributes, less managerial capabilities, absence of marketing skills, low technological capabilities are key internal variables that account for fluctuations in and limit SMEs' growth.

Away from the above, Ruskov et al. (2012) reported that web contents offer strong competitive advantage which can equally help firm to grow. Beside, Cant and Wiid (2013) revealed that competition is a major macro environment factor that influences the SMEs in the country. Cant and Wiid further postulated that improper pricing strategies, low demand for products, location of the business and the knowledge of the segmented audience constitute the key marketing factors. Thus competition in the industry can influence SMEs decisions to invest. Hence, the hypothesis is formulated as,

\section{$\mathrm{H}_{2}=$ Competition will relate negatively to SMEs WTI}

Corruption: There are adequate research evidence (Soini \& Veseli, 2011; Rune, 2011; Gbetnkom, 2012; Tsalikis and Peralta, 2014; Kanu, 2015; Koudelkova \& Senichiev, 2015; Galli, et al., 2017; Sulemenova et al., 2018) on effect of corruption on firm investment decision, growth and development. Kanu (2015) discovered that corruption has positive impact on price, and adversely relates to growth, productivity, and employment. Furthermore Kanu (2015) indicated that corruption rekindles extortion by government authorities.

In a related study, Gbetnkom (2012) found that tax inspectors, police officers, hygiene and epidemiological officers, authorities from ministries and other public institutions, custom officers and electricity officers exert pressures on business operators/owners for illegal payments. However, the study revealed that bank officials and telecommunication officials are less corrupt. Again, the study showed that corruption retards the process of SMEs' advancement. Rune (2011) found that there is not uniform or acceptable standards on the contextual variables like the nature and degree of corruption in a particular market, societal and cultural features of a nation including its regulatory bodies, and the intention and effort of a firm to prevent it from occurring. Again, the study noticed that the financial costs of administrative corruption was hard to estimate since facilitation payments would frequently favor SMEs with regards to diminishing bureaucratic limitations and save precious time in day-to-day business operations.

In a similar tone, Sulemenova etal. (2018) reported that there is a gap between corruption perception and the extent to which SMEs are included in the corruption. Moreover, the study revealed that SMEs representatives admitted that bribe (a type of corruption) has been the mean to resolve problems hastily. In Kosovar, Soini and Veseli (2011) found huge number of elements exerting effect on the country's SMEs advancement, however the key elements are lack of access to finance, completion, corruption, internationalization, laws and regulations, management competence, lack of skilled labor, and low investment innovation, technology and marketing.

A study in Czech Republic by Koudelkova and Senichiev (2015) reported that most of the people in the country regarded corruption to be spreading widely. Again, the authors indicated that corruption is a serious hindrance to the smooth business performance. Furthermore, the study suggested that business ethical decision-making must be reconsidered Galli et al. (2017) and Tsalikis and Peralta (2014) reported that particular socio-institutional setting will influence the degree of corruption among micro, small and medium-sized enterprises (MSMEs). Galli et al. suggested that anti-corruption policies and measures aiming to smooth transparency in the economy could be vital in eliminating the adverse effects produced by a lessquality institutional setting on the access to credit by small companies. Again, the study suggested that policymakers must mediate in corrupt prone areas with the purpose of reducing the corruption blight. Therefore the study assumes that corruption perception will influence SMEs decisions to invest in the Ghanaian oil and gas sector. From the on-going we proposed the hypothesis as follow, 


\section{$\mathrm{H}_{3}=$ Corruption will relate negatively to SMEs WTI}

Policy Awareness/Institutional Support: There are numerous studies on policy awareness and institutionalization effect on SMEs growth and investment decisions (McGrath \& O’Toole, 2011; Christina et al., 2014; Kilbret et al., 2015; Mohamad et al., 2015; Chimucheka \& Mandipaka, 2015; Lampadarious, 2016; Gumel, 2017). A study by Christina et al. (2014) examined the particular difficulties SMEs owners face. The study showed that most of SMEs encounter enormous challenges in the manner of policy and administration as well as marketing and financial cases.

Moreover, Kilbret et al. (2015) determined the opportunities and challenge of small enterprises and dived into the policy and regulatory issues in the growth and success of the sector. The study found that higher tax, ineffective tax administration, prices of inputs, bureaucratic difficulties, absence of raw materials, insufficient skills, higher interest rates and unbearable collateral demands are main barriers to the increase of small businesses. Again, the study suggested that government and non-governmental organizations must coordinate regulatory and institutional assistance such as business premises, softening bureaucratic procedures, financial services and trainings, in order increase the small enterprises to culminate into economic success and job generation.

Furthermore, McGrath and O’Toole (2011) examined SMEs challenges in adopting the approach in practice. The study asserted that policy awareness and creation of networks in an industrial wise is very crucial, since in the presence of awareness, marketing route via extant and potential networks could devise some means from the resource/time pressure on the SME marketing practitioners. The study therefore argues that lack of policy awareness will affect SMEs investment decisions. Hence, the hypothesis is formulated as,

\section{$H_{4}=$ Lack of policy awareness will relate negatively to SMEs WTI}

External Financing: There are many research works (Rupeika-Apoga, 2014; Zidana, 2014; Prempeh, 2015; Eniola \& Entebang, 2015; Preprah, 2016; Waked, 2016; Wang, 2016; Haron \& Ibrahim, 2016) that had reported on challenges facing SMEs access external funding. Rupeika-Apoga (2014) investigated challenges within SMEs financing for three Baltic States and equipped the government and other stakeholders with instruments to comprehend SMEs' financing needs. The study identified the relevance of optional resources of external financing available for small emerging economies like Baltic States as well as the urge to assist the design and assessment of policy measures and check on the consequences of financial reforms of SMEs' access to finance.

Reporting from Ghana, Preprah (2016) assessed the accounting variables banks take into consideration prior to the giving out loans to SMEs and compared the problems SMEs encounter in accessing bank loans between Finland and Ghana. The study found that banks universally consider SMEs to have more credit risk than the large corporations. Again, the study indicated that banks also check on the managerial attitude, capacity, environmental terms and collateral guarantee before decide to grant loans or not. Furthermore, the noticed those Ghanaian banks are very much particular about collateral guarantee for the reason that SMEs are associated with higher risk of loan. Weak business proposal/plan, non-lucrative venture decisions, disadvantageous governmental economic policies and inadequate collateral were found by the study as some of problems SMEs encounter in accessing bank loans.

In Saudi Arabia, Waked (2016), explored the form of finance that are readily in place for SMEs in the country through detecting exogenous and endogenous sources of funds. The study revealed the exogenous and endogenous barriers like availability of capital, competition, consumer satisfaction and marketing to be relevant hampers to the performance of business. Furthermore, the study made a number of suggestions for improving the SME sector in the country, and to encourage access to finance from banks via developing association of trust among the SMEs and banks. 
Wang (2016) reported that SMEs consider access to finance as the major relevant barrier that hampers their advancement. The main accounting factors among the firms' attributes were found by the study to size, age and growth rate of firms and the firm's ownership. Again, the study revealed that the key hampers to exogenous financing are exorbitant cost of borrowing and absence of consultant assistance. Furthermore, the study showed that highly grown firms regard finance as the largest barrier to growth, and this manifests the popular beliefs that high growth firms exhibit higher demand for funds compared to feeble growth firms. In Nigeria, Eniola and Entebang (2015), sought to shed light on the sources of finance for SMEs, analyzed the difficulties in getting finance for SMEs with the purpose of employing innovative approaches to increase credit facilities. The study recommended that for SMEs in the country to become critical and indispensable to the national development, innovative systems must be employed to increase SMEs' access to finance through crowd funding. Hence, the hypothesis is formulated as.

\section{$H_{5}=$ Lack of external funding will relate negatively to SMEs WTI}

Information flow: Another challenge that affects small and medium enterprises is lack of access to reliable information. Businesses cited in Africa suffer immensely from inadequate business information from both service providers and government institutions (Chopra et al., 2007; Oshikoya \& Hussian, 2007; Hamisi, 2010; Nyang'au 2013; Kamunge et al., 2014; Yoshino \& Taghizadeh-Hesary, 2016; Emezie 2017). The major problem arises from poor environmental information emanating from the business fraternity due to undeveloped communication infrastructure and technological inadequacies (Kamunge et al., 2014; Oshikoya \& Hussain, 2007). The availability of technological gadgets and hardware make it easy to effectively and efficiently reduce costs of production and operations in which there is the need for governments in Africa and non-governmental organizations to play their roles to improve conditions.

Emezie (2017) examined the prospects and challenges of SMEs in Africa in the $21^{\text {st }}$ century and the study found that the lack of effective managerial skills, information and wrecked ways of keeping information. The African business owners are less educated and lack the knowledge in keeping data, which helps to check the performance of the business and make amends where necessary. In the study, Emezie (2017) found that business owner belief record keeping is not all that important to the course of their business operations while those who keep record do so in haphazard manner. It is shocking to know that businesses consider record keeping being less important.

Chopra et al. (2007) indicated that sharing of information across the entire supply chain makes SMEs operate effectively. Sharing and getting access to accurate information improves stocks, customer feedbacks and decision-making. As found by Hamisi (2010) the effective flow of information across supply chain partner's links up with immediate and long term developments. This simply implies that, the inadequate sharing of information along the supply chain distorts networks, increases shortage, prices and accelerates demand for products. There is therefore the need to adopt measures to control and manage inventory. Sharing of information is key in coordinating and integrating effectiveness to achieve maximum profitability that leads to cost effectiveness and responsiveness. For inventory management to be effective, information sharing must be accurate which controls stocks, customer performance, cost across suppliers, wholesalers, shipment, retailers and customers, distributors and manufacturers. SMEs depend heavily on information to function in their relation with their suppliers and customers to make effective decision. Hence, the hypothesis is formulated as,

\section{$H_{6}=$ Inadequate information flow will relate negatively to SMEs WTI}

Human resources capacities: Human resources are required to effectively manage firm's resources. Many previous studies (Chandler \& McEvoy, 2000; Beaver \& Hutchings, 2005; Omar et al., 2009; Abdullah 2009; Islam \& Siengthai, 2010; Adnan, Abdullah \& Ahmad 2011; Hamdani \& Wirawan, 2012; Peprah 2016; Eton et al., 2017) have reported on the need to have efficient human resources structure in place to enhance 
growth and development. Hamdani and Wirawan (2012) reported that the major factors that affect SMEs include; access to capital and human resource, marking skills, equipment and technology.

Human resource training and development enhances employee capacity that leads to effective contribution of employees to organizational growth. In an interview with 58 human resource managers, three main challenges were identified and these are lack of intellectual human resource development professionals, fostering learning and development at the workplace and coping with demand for knowledge (Abdullah, 2009). Adnan, Abdullah and Ahmad (2011) reiterated that HRM practices indeed have immense contribution to performance which means management practices influence business performance. Islam and Siengthai (2010) in his submission declared that the core mandate of HRM in recruiting, selection, conduction of performance appraisal and training and development have positive effect on the success of a company. Agwu \& Emeti (2014) found that lack of managerial competency is the key problem SMEs encounter in their endeavor to succeed. This implies the knowledge, skills and experience of enterprise owners and managers. Furthermore, the study defined competency as managerial capacity to blend tangible and intangible assets to nurture strategic effort to increase performance and efficiency (Muriithi, 2015).

Fouad (2013) found that that the manufacturing SMEs have a problem of insufficient managerial skills. Therefore, the findings of the study corroborates the assertion that ineffective management skills like human resources management, financial management, general management, production management and marketing management lead to abysmal performance of SMEs in the manufacturing sector of the city of Cairo. Again, the study indicated that absence of skilled human resources increases abysmal performance of SMEs in the manufacturing sector of the country. The development of SMEs depends greatly on the activities of HRM. Hence, we proposed the hypothesis as,

\section{$H_{7}=$ Inadequate human resources capabilities will relate negatively to SMEs WTI}

Entrepreneur Characteristics: Most SMEs lack the requisite entrepreneurial skills to explore investment opportunities and enhance their competitiveness (Islam et al., 2011; Sidika, 2012; Kazimoto, 2014; Abood et al., 2014; Chinonso \& Zhen, 2016). Inappropriate managerial activities also prevent banks from offering loans to SMEs. In order to improve the chances of SMEs access to loans, they have to develop the integrity of entrepreneurs through positive financial management and business practices (Chinonso \& Zhen, 2016). Islam et al. (2011) found that entrepreneurial characteristics increase the success of SMEs.

Small business owners should be more enthused about their products and services and be willing to be personally involved and to stick with their policies. There is the need for SMEs to build strong business networks including developing government relationships. The outcome of business emanates from how business is being done. Business success also comes through inter-firm cooperation, flexibility performance measurement and consultation. Linking up with other firms contributes to gaining organizational legitimacy and helps to develop good market reputation. Kazimoto (2014) evaluated the problems that small and medium-sized enterprises (SMEs) encounter regarding global marketing standards. The study found that small and medium-sized enterprises encounter problems in accessing global marketing in limbo of regulations and standards, absence of financial assistance from the government, vague meaning of consumers' needs and services, absence of appropriate entrepreneurial skills and poor networking structures to enter into global marketing. We argue that lack of efficient human management structure will tremendously affect SMEs investment decisions in the Ghanaian oil and gas sector. Hence, the hypothesis is formulated as.

\section{$H_{8}=$ Inadequate entrepreneurial characteristics will relate negatively to SMEs WTI}

Technological capacities: Past research reports had revealed that majority of SMEs have not subscribed to the emerging technological trend hence many of them are lagging behind their large firm counterparts (Soon 2006; Asare, 2014; Ocloo et al., 2014; Farsi \& Togharee, 2014; Bouazza et al., 2015). Farsi \& Toghraee (2014) found that even the little advanced business entrepreneurs are frequently live in limbo 
of these new technologies and even if they aware of them, it inapplicable in the local context or not affordable as well as in disharmony with the indigenous situations. Moreover, the study found that foreign companies are still the frontiers in terms of implementing new technologies.

In Algeria, Bouazza et al. (2015) investigated into the variables that affect the growth rate of small and medium-sized enterprises (SMEs) in the country. The study found that out of the large problems in the development process of SMEs in the country, the absence of technological capacities is the most serious and this form the bedrock of improving competency of SME owners and managers. Again, the study indicated that technological capabilities are regarded as instruments for increasing the competitiveness of SMEs. Furthermore, the study argued that small and medium-sized enterprises (SMEs) could enhance their production effort and profitability through advancing their technological capacities. Soon (2006) found the absence of capacities and resources, ineffective management, low-level of technology, competition, and economics and, technological, socio-cultural and global variables constitute the exogenous and endogenous environmental elements.

In Ghana, Asare (2014) found that financial institutions and government must ensure that funds are available to be accessed by SMEs at affordable interest rate to support their increase and success in this economy sector of the country, because of being the main stakeholder in unemployment elimination and poverty eradication. Nonetheless, the study recommended that government must ensure the availability of incentive for SMEs' that has entry into specific industries like technological industries to foster the local technological competence and capacities. Hence, the hypothesis is formulated as,

\section{$H_{9=}$ Inadequate technological capacity will relate negatively to SMEs WTI}

\section{RESEARCH METHODOLOGY}

\section{Study Location/Context}

Ghana is located on the Sub-Sahara African terrain and has Accra as its administrative capital city. The country has a population size of 28.31 million (GSS, 2016). It practices democratic system of governance with multi-party system and parliamentary representatives. The country is endowed with precious natural minerals like gold, diamonds, manganese ore, bauxite, and other productive resources like hydrocarbons and industrial minerals. Ghana is next to South Africa, the leading gold producer in Africa and still next to the leading cocoa producer. The combination of the above factors has increase the country's GDP per capita to the highest within West Africa due to a GDP rebasement, during 2011 Ghana was ranked as the fastest growing economy on the large globe. In the period of June and August 2007, in the face of international food and oil calamity, oil was discovered on the shores of the country by the UK-based firm Tullow oil, as well as its business partners Kosmos Energy and Anadarko Petroleum. 1.8 billion barrels of crude oil was estimated at the initial stage after the discovery, and its full production was scheduled to be in 2010. Initially, reports circulated around that the country's reserves were relative in amount to that of Nigeria and Angola (Bawumia \& Halland, 2017). The country's expansionary fiscal policy in 2007 to 2008 churned out significant implications, and therefore the economy experienced development reverse: inflation escalated from $10.9 \%$ at the close of 2006 to $18.1 \%$ in the latter part of 2008 , exchange rate depreciated by $20.1 \%$ in 2008 higher than $1.1 \%$ in 2006. Gross international reserves reduced from US $\$ 2.27$ billion (three months of import cover) in 2006 US $\$ 2.04$ billion (1.8 months of import cover) in 2008. Government of Ghana has the decision to ensure proper management of the country's oil resources in order to prevent any fatal curse (Amoako-Tuffour \& Ghanney, 2013). This study will therefore have both practical and theoretical implications on SMEs participation in the Ghanaian oil and gas sector. 


\section{Research Design}

This study utilized a quantitative research design to address the established study objective and set of hypotheses. Quantitative research design permits the use of numerical estimations to measure the possible outcome. Usually, quantitative research complies with positivism and objectivity conception of social reality. Moreover, quantitative design sanctions the collection and analyses of numerical data, usually with the aid of appropriate statistical software (Fox \& Bayat, 2007). In this study quantitative research design is deployed to numerically measure the extent of SMEs WTI base on number of constraints.

\section{Population and Sampling Design}

The population of this study comprised of all registered SMEs which have affiliation with National Board for Small Scale Industries (NBSSI) and Ghana Chamber of Commerce and Industry (GCCI) in the Kumasi metropolis of Ghana. Also, the participants were studied in their natural habitat- implying that the study was carried out in non-contrived setting. Morgan and Krecie (1970) statistical formula was used to determine the 497 (383+Non-Response) sample size. Stratified sampling (equal chance of being selected) technique was used to select the entire participants (Zikmund et al., 2012). Using SMEs industry as the strata, the following groups (Manufacturing, Service and Retailing) were established. Random sampling techniques such as stratified sampling technique are very effective in reducing sampling errors and enhancing fair representatives. Moreover, Appiah et al (2018) used similar sample size and sampling technique in their recent publication. These imply that the choices are known and acceptable by economists.

\section{Data Collection and Analyses}

There are two main known types of data for most scientific studies. Namely; primary and secondary data. In this study primary data was utilized using structured questionnaires and categorical (nominal) scale of measurement. Some researchers (Saunders et al., 2012; Zikmund et al., 2012) argued that if studies exert quantifiable attributes then survey by questionnaire is the most suitable choice. Although individuals answered the questionnaire the unit of analysis for the study was at the organizational level. Moreover, this study was a cross sectional hence data were gathered at a particular time period. The variables use for the study was Inadequate Capital, High Level of Competition, Corruption, Lack of Policy Awareness, Inadequate Access External Financing, Inadequate Entrepreneur Characteristics, Inadequate Management Capabilities Capacities and Technological Capabilities. Detail description of the study variables are given in Table 1. The Statistical Package for Social Sciences (SPSS) version 23 was the main statistical software used in this study to conduct chi-square and binomial regression analysis. All the proposed hypotheses for the study were tested at 0.05 significance level.

Table 1

Description of the Variables and Proxies used to Measure WTI

\begin{tabular}{|c|c|c|c|}
\hline Constructs/Variables & $\begin{array}{c}\text { Variable } \\
\text { Description }\end{array}$ & $\begin{array}{c}\text { Hypotheses } \\
\text { Effects }\end{array}$ & Variable Sources \\
\hline Dependent & Willingness to invest or not & & \\
\hline Inadequate Capital & $\begin{array}{c}\text { Size of capital (value of fixed assets } \\
\text { owned by the company expressed in } \\
\text { Ghana cedis) }\end{array}$ & - & $\begin{array}{c}\text { Wanomo etal., 2012; } \\
\text { Stein et al., 2013; } \\
\text { Quartey etal., 2017 }\end{array}$ \\
\hline $\begin{array}{c}\text { Inadequate Entrepreneur } \\
\text { Characteristics }\end{array}$ & $\begin{array}{c}\text { Entrepreneurial characteristics (the } \\
\text { knowledge and skills to effectively } \\
\text { combine other factors of production } \\
\text { to achieve a desire results) }\end{array}$ & - & $\begin{array}{c}\text { Bouazza et al. } \\
\text { Peprah 2016; Eton } \\
\text { et al., 2017 (2015). }\end{array}$ \\
\hline Inadequate Management \\
Capabilities & $\begin{array}{c}\text { Management capacities (the ability to } \\
\text { organize, plan, control and direct the } \\
\text { affairs of the business effectively) }\end{array}$ & - & $\begin{array}{c}\text { Bouazza etal. (2015). } \\
\text { Peprah 2016; Eton } \\
\text { etal., (2017 }\end{array}$ \\
\hline
\end{tabular}




\begin{tabular}{|c|c|c|c|}
\hline $\begin{array}{c}\text { Capacities Technological } \\
\text { Capabilities }\end{array}$ & $\begin{array}{c}\text { Technological capacities (the } \\
\text { knowledge and ability to adopt to } \\
\text { emerging innovations) }\end{array}$ & - & $\begin{array}{c}\text { Bouazza et al. } \\
(2015) .\end{array}$ \\
\hline Inadequate External Financing & $\begin{array}{c}\text { Access to credit facilities from other } \\
\text { sources external to SMEs }\end{array}$ & $\begin{array}{c}\text { Wanomo etal., 2012; } \\
\text { Preprah, 2016) } \\
\text { Waked (2016) }\end{array}$ \\
\hline High level of Competition & $\begin{array}{c}\text { Competition (The degree of opposing } \\
\text { forces or rivalry among firms) }\end{array}$ & $\begin{array}{c}\text { Ayyagari et al. } \\
\text { (2011); Wanomo } \\
\text { etal. (2012) Quartey } \\
\text { etal., (2017). }\end{array}$ \\
\hline Inadequate information flow & $\begin{array}{c}\text { Information (Access to information } \\
\text { about contracts and procedure) }\end{array}$ & - & $\begin{array}{c}\text { Ayyagari et al. 2011; } \\
\text { Abuka etal., 2006; } \\
\text { Wanomo etal., 2012; }\end{array}$ \\
\hline Lack of Policy Awareness & $\begin{array}{c}\text { the extent to which SMEs are } \\
\text { adequately informed about oil and gas } \\
\text { Policies including investment } \\
\text { opportunities }\end{array}$ & - & $\begin{array}{c}\text { Lampadarious, } \\
\text { (2016); Gumel } \\
(2017)\end{array}$ \\
\hline Corruption Perception & $\begin{array}{c}\text { The degree of dishonest exploitation } \\
\text { among oil and gas officials }\end{array}$ & - & $\begin{array}{c}\text { Galli, et al. (2017); } \\
\text { Sulemenova et al. } \\
(2018)\end{array}$ \\
\hline
\end{tabular}

Source: Authors' compilation

\section{The Use of Logit Regression and Justification}

In statistics, binary logistic (logit) model is used to estimate the probability of a binary response based on one or more predictors (Cox, 1958). Logit model does not hold the same assumptions as the case of linear regression and general linear models which employ ordinary least squares (OLS) algorithms including; normality, linearity, homoscedasticity and measurement level. Specifically in logit model the relationship between dependent and independent variables is not required to be linear. Moreover, normal distributions of error terms (residuals) are not necessarily needed in logit model. Homoscedascity is not required in logit model. Also, logit model the dependent variable is not measured on interval or ratio scale. Meanwhile, in logit model some assumptions still apply particularly the dependent variable is required to be binary and ordinal. Again, logit model requires the observations to be independent of each other. The model specifications had been explained in details below.

\section{Model Specifications}

The Logit model does not require the dependent variable (WTI) to be neither linear nor normal function of the independent variables with an error term $\left(\varepsilon_{i}\right)$. Moreover, homoscedasticity and measurement level are both not required in logit modelling. However, the study assumes a linear function between the relationship between the independent variables (Inadequate Capital $=(\mathrm{IC})$, High Level of Competition $(\mathrm{HLC})$, Corruption $=(\mathrm{CP})$ Lack of Policy Awareness $=(\mathrm{LPA})$, Inadequate Access External Financing $=$ (IAEF), Inadequate Entrepreneur Characteristics (IEC), Inadequate Management Capabilities = (IMC), Capacities Technological Capabilities $=($ CTC) and the dependent variable (WTI) is linear. This has been explained in the model equation below.

Thus,

$$
\operatorname{Logit}(\mathrm{P})=\log (\mathrm{P} / 1-\mathrm{P})=\log (\mathrm{p})-\log (1-\mathrm{P})
$$

This is in reduced form of a Logit model can be expressed as:

$$
\mathrm{Y}=\alpha+\beta \mathrm{iXi}+\varepsilon
$$


Where:

$$
\begin{gathered}
\text { WTI } I_{i}=\text { Willingness to Invest } \\
\alpha=\text { The intercept } \\
\beta_{i}=\text { coefficient of independence variables } \\
\mathrm{X}_{i}=\text { independent variables } \\
\varepsilon_{i}=\text { The error term }
\end{gathered}
$$

Model (1)

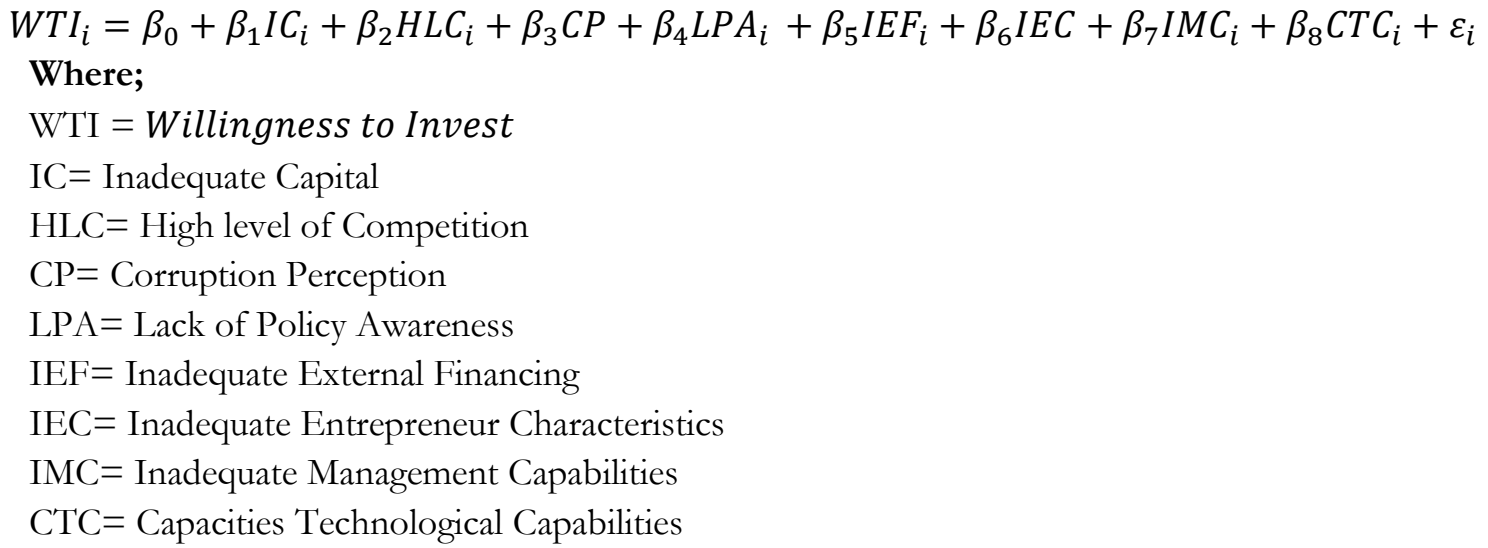

$$
\varepsilon_{i}=\text { The error term }
$$

\section{RESULTS AND DISCUSSIONS}

With all the statistical models to test goodness of fit Chi-square $\left(X^{2}\right)$ was used. This is because $X^{2}$ supports categorical (nominal) data such as those used in this study. Table 2 presents the Chi-square $\left(X^{2}\right)$ Goodness of fit test to establish the effects of investment constraints factors on SMEs WTI in the Ghanaian oil and gas sector. The survey results show that inadequate capital, high level of competition, corruption perception, lack of policy awareness, inadequate external financing, information flow, inadequate, inadequate managerial capabilities, technological capabilities had significant association with SMEs WTI. However, inadequate human resources capabilities inadequate entrepreneur characteristics had no significant association with SMEs WTI in the Ghanaian oil and gas value chain. Phi $(\varphi)$ values were determined to measure the strength of correlation between the each predictor and the constant using 497 simple size.

Table 2

Chi-Square Analysis Results

\begin{tabular}{|l|c|c|c|c|c|}
\hline Perceived Constraints & $\begin{array}{c}\text { Chi square } \\
\left(\mathbf{X}^{2}\right)\end{array}$ & $\boldsymbol{D f}$ & $\begin{array}{c}\text { Phi }(\boldsymbol{\varphi}) \\
\text { value }\end{array}$ & P-value & $\begin{array}{c}\text { Hypothesis } \\
\text { Decisions }\end{array}$ \\
\hline IC & 52.082 & 1 & 0.324 & $0.000^{* *}$ & Supported \\
\hline HLC & 49.525 & 1 & 0.316 & $0.000^{* *}$ & Supported \\
\hline CP & 24.075 & 1 & 0.220 & $0.000^{* *}$ & Supported \\
\hline LPA & 49.619 & 1 & 0.316 & $0.000^{* *}$ & Supported \\
\hline INFOR & 7.110 & 1 & 0.120 & $0.008^{* *}$ & Supported \\
\hline IEF & 5.055 & 1 & 0.101 & $0.025^{* *}$ & Supported \\
\hline HRC & 0.262 & 1 & 0.023 & 0.609 & Unsupported \\
\hline IEC & 1.490 & 1 & 0.055 & 0.222 & Unsupported \\
\hline IMC & 11.544 & 1 & 0.152 & $0.001^{* *}$ & Supported \\
\hline ITC & 5.064 & 1 & 0.101 & $0.024^{* *}$ & Supported \\
\hline
\end{tabular}

Source: Field data $*$ significant at $95 \%(\mathrm{p}=0.05) * *$ significant at $90 \%(\mathrm{p}=0.1)$ 


\section{The Logistic Regression Model results}

A binary logistic regression had been used to estimate the effects of inadequate capital, high level of competition, corruption perception, lack of policy awareness, inadequate external financing, information flow, inadequate, inadequate managerial capabilities, technological capabilities on the likely event that SMEs were WTI in the Ghanaian oil and gas sector.

$$
\operatorname{Logit}(\mathrm{P})=\log (\mathrm{P} / 1-\mathrm{P})=\log (\mathrm{p})-\log (1-\mathrm{P})
$$

\section{The final estimated model is;}

Model (1)

$$
\begin{gathered}
W T I_{i}=\beta_{0}+\beta_{1}-1.102_{i}+\beta_{2}-1.134_{i}+\beta_{3}-0.912_{i}+\beta_{4}-0.703_{i}+\beta_{5}-1.393_{i}+\beta_{6}-0.548 \\
+\beta_{7}-0.282_{i}+\beta_{8}-0.263_{i}++\varepsilon_{i}
\end{gathered}
$$

The explanatory power of the model was determined using both Cox and Snell R2 and Nagelkerke R2. From the model the explanatory power of the logit model ranges from $17.3 \%$ to $26.9 \%$ respectively for Cox and Snell $\mathrm{R}^{2}$ and Nagelkerke $\mathrm{R}^{2}$ and correctly classifies $83.1 \%$ of the cases suggesting a good model.

Table 3

Binary Logistic Regression Analysis Results

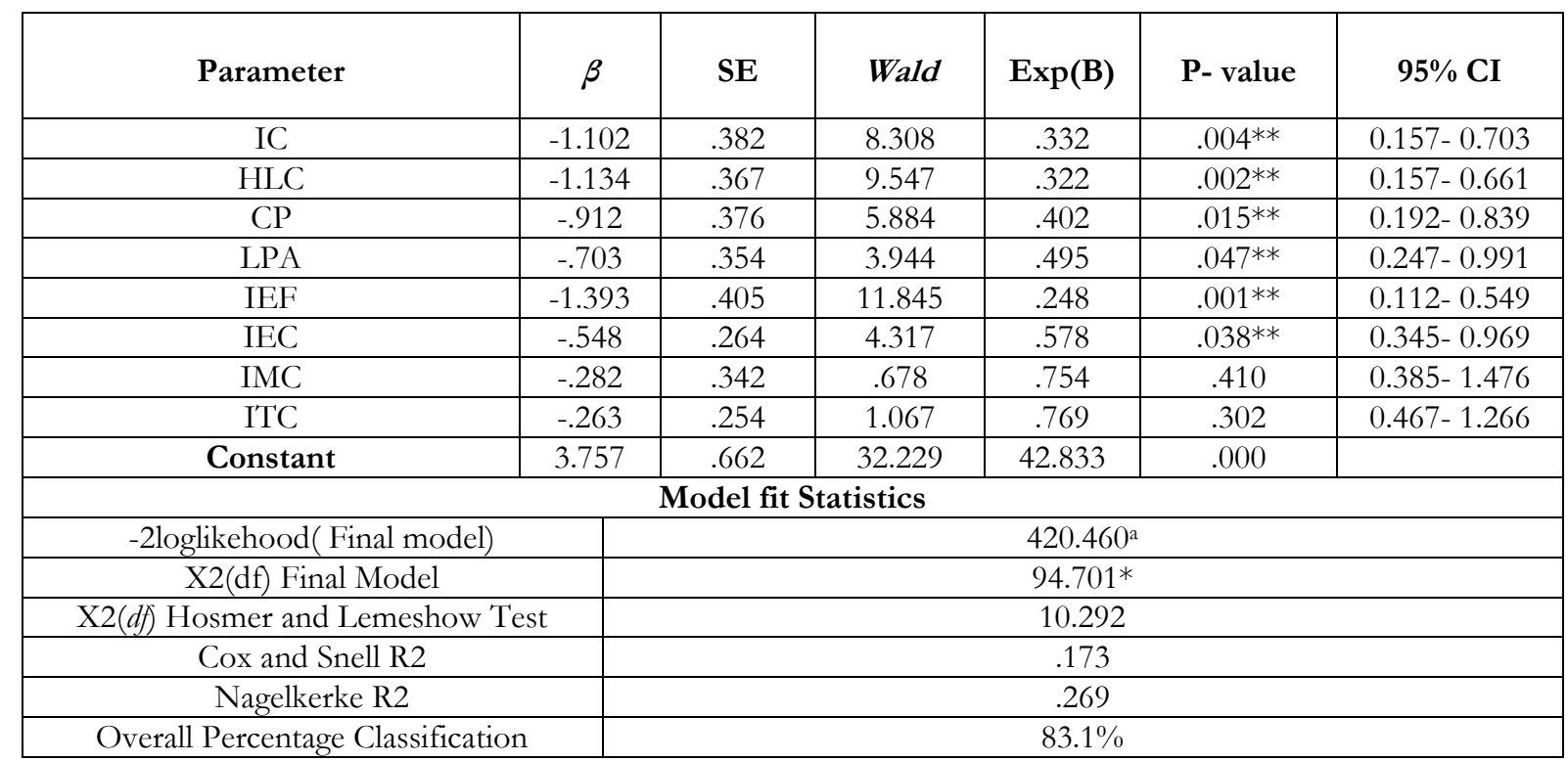

Source: Primary data $* *$ significant at $5 \%$ and $*$ significant at $10 \%$

\section{Impact of policy environment on SMEs WTI as Interpreted from the Model}

This study was aimed to model the dimensions of SMEs constraints on WTI in the Ghanaian oil and gas sector. As indicated in Table 3, several investment constraints affect SMEs WTI. From the survey the strongest investment constraint affecting SMEs WTI was inadequate access to external finance $\beta=-1.393$, $\mathrm{p}<0.05)$. The result suggests that a unit decrease in SMEs access to external fiancé brings about $139.3 \%$ decreases in SMEs willingness to invent in the oil and gas sector. This result leans support to previous studies that suggested lack of external financial access as a major constraint to SMEs investment. Several other researchers (Rupeika-Apoga, 2014; Zidana, 2014; Prempeh, 2015; Eniola and Entebang, 2015; 
Preprah, 2016; Waked, 2016; Wang, 2016; Haron and Ibrahim, 2016) have reported on constraints facing SMEs bid to access external funding. For instance, Rupeika-Apoga (2014) investigated challenges within SMEs financing for three Baltic States and found that the presences of financial funds heavily rely on the degree of company's success, the bigger and popular are the companies the wider choices available to them. Furthermore, the study indicated the availability of business angels, venture capital funds, government various support programs and seed funding as alternative resources for new firms, over the bank loans.

The survey revealed that high level of competition is a determinant of SMEs WTI $(\beta=-1.134, \mathrm{p}<0.05)$. The implication of this result is that a unit change in the level of completion will result is $113.4 \%$ decrease in SMEs WTI in the Ghanaian oil and gas sector. This result corroborates with past studies which reported that SMEs investment constraints are affected by high level of competition in the business environment. More especially foreign direct investment and trans-national corporations have exacerbated the investment plight of most SMEs due to the fierce competitions introduce by these high profile companies. Previous researchers (Morone \& Testa, 2005; Ruskov et al., 2012; Cant \& Wiid, 2013; Bouzza et al., 2015; Sitharam \& Hoque, 2016) emphatically reported that competitions pose major challenge to SMEs investment choices. Relatedly, Sitharam and Hoque (2016) found that competition is considered to be the key problem as the only variable among the rest that has relevant link to SMEs' performance. Furthermore, Sitharam and Hoque further suggested that SMEs must get ready for indigenous and global competition. Hence, collaboration among SMEs would be the mode for SMEs to cope with competition. In similar tone, Morone and Testa (2010) reported that SMEs are not able to compete strongly in exporting business.

Moreover, the study found that Inadequate Capital was a determent of WTI $(\beta=-1.102, p<0.05)$. This suggests that a unit decrease in investment capital will result in 110.2\% decrease in SMEs WTI. Inadequate capital requirement had been major SMEs investment constraint in most African countries particularly micro and small enterprises. This result further affirms the findings of previous studies (Ackah \& Vuvor, 2011; Lyimo, 2014; Orinda, 2014; Fuseini, 2015; Arthur, 2015; Ayevor, 2016; Taghizadeh-Hesary, 2016) reported that inadequate credit access had been a leading challenge among SMEs of all categories. In Ghana, Ayevor (2016) found that SMEs encounter numerous difficulties when seeking funds from formal financial institutions in the country. Beside, Arthur (2015) found that SMEs face number of problems in their dealing particularly meeting the requirement of formal financial institutions despite the sector's contribution to national success via business, financial and managerial training initiatives.

The study discovered that corruption perception $(\beta=-0.912, \mathrm{p}<0.05)$ is a major determinant of WTI. The result implies that a unit change in corruption perception will result in $91.2 \%$ decrease in SMEs W'TI in the Ghanaian oil and gas chain value. There are number of studies which have reported similar findings. This study herein confirms that the level of corruption both perceived and actual have detrimental effect on SMEs WTI. There are adequate research evidence (Soini \& Veseli, 2011; Rune, 2011; Gbetnkom, 2012; Tsalikis \& Peralta, 2014; Kanu, 2015; Koudelkova \& Senichiev, 2015; Galli, et al., 2017; Sulemenova et al., 2018) on effect of corruption on firm investment decision, growth and development. Kanu (2015) reported that corruption decreased SMEs owner/managers' access to finance. Furthermore, the study indicated that corruption rekindles extortion by government authorities. Moreover, Gbetnkom (2012) revealed that tax inspectors, police officers, hygiene and epidemiological officers, authorities from ministries and other public institutions, custom officers and electricity officers exert pressures on business operators/owners for illegal payments. The outcome of the study is also affirm by Rune (2011) who reported that there is not uniform or acceptable standards on the contextual variables like the nature and degree of corruption in a particular market, societal and cultural features of a nation including its regulatory bodies, and the intention and how to prevent it from occurring.

The study found that lack of policy awareness $(\beta=-0.703, \mathrm{p}<0.05)$ was a determinant of WTI. This result suggests that a unit change in policy awareness will result in $70.30 \%$ decrease in SMEs WTI in the 
Ghanaian oil and gas sector. The preponderance previous studies are supported by this study. There are enough reasons to suggest that when SMEs are not supplied with the necessary policy information investment would most likely be affected. There are numerous studies on policy awareness and institutionalization effect on SMEs growth and investment decisions (McGrath \& O’Toole, 2011; Christina et al., 2014; Kilbret et al., 2015; Mohamad et al., 2015; Chimucheka \& Mandipaka, 2015; Lampadarious, 2016; Gumel, 2017). A study Christina et al. (2014) examined the particular difficulties SMEs owners face. The study showed that most of SMEs encounter enormous challenges in the manner of policy and administration as well as marketing and financial cases.

The study found that Inadequate Entrepreneur Characteristics $(\beta=-0.548, \mathrm{p}<0.05)$ was a determinant of WTI. This result implies that a unit change in entrepreneurial capabilities will result is $54.8 \%$ decrease SMEs willingness to invest. Lack of adequate entrepreneurial capabilities affect SMEs ability to explore their immediate business environment and tap investment opportunities. Most SMEs lack the requisite entrepreneurial skills to explore investment opportunities and enhance their competitiveness (Islam et al., 2011; Sidika, 2012; Kazimoto, 2014; Abood et al., 2014; Chinonso and Zhen, 2016). Inappropriate managerial activities also prevent banks from offering loans to SMEs. In order to improve the chances of SMEs access to loans, they have to develop the integrity of entrepreneurs through positive financial management and business practices (Chinonso and Zhen, 2016). This result confirms that assertion that SMEs in most developing and emerging economies are not well equipped with the entrepreneurial skills and mindset to explore beyond their comfort zone.

Surprisingly, the study found that inadequate technological capacities $(\beta=-0.263, \mathrm{p}<0.05)$ is not significant determinants of WTI. Meanwhile, it exerts negative associations on SMEs willingness to invest. Past research revealed that majority of SMEs have not subscribed to the emerging technological trend hence many of the SMEs are lagging behind their large firm counterpart (Soon 2006; Asare, 2014; Ocloo et al., 2014; Farsi \& Togharee, 2014; Bouazza et al., 2015). Farsi \& Toghraee (2014) found that even the little advanced business entrepreneurs are frequently live in limbo of these new technologies and even if they aware of them, it inapplicable in the local context or not affordable as well as in disharmony with the indigenous situations.

Last but not the least, the study found that inadequate managerial capacities $(\beta=-0.282, \mathrm{p}<0.05)$ are not significant determinants of W'TI. Previous studies (West Wood, 1972; Roger, 2002; Fouad, 2013; Agwu \& Emeti, 2014; Muriithi, 2015; Oyelana \& Smith, 2015; Rahman et al., 2016) revealed that due to lack of managerial skills most SMEs extinct. Agwu \& Emeti (2014) found that lack of managerial competency is the key problem SMEs encounter in their endeavor to succeed. This implies the knowledge, skills and experience of enterprise owners and managers. Furthermore, the study defined competency as managerial capacity to blend tangible and intangible assets to nurture strategic effort to increase performance and efficiency (Muriithi, 2015).

\section{CONCLUSIONS AND IMPLICATIONS}

This investigated the effects of investment constraints on SMEs WTI in the Ghanaian Oil and Gas Sector using a binominal regression model. The study had revealed that that inadequate capital, high level of competition, corruption perception, lack of policy awareness, inadequate external financing significantly decrease the odds of SMEs investment in the oil and gas industry. However, inadequate human resources capabilities inadequate entrepreneur characteristics had no significant association with SMEs WTI.

The main policy implication emanating from the study is that SMEs cannot actively participate in the high-value oil and gas sector due to vast number of internal and environmental constraints. This implication supports a pool of literature earlier reported on SMEs investment barriers. For instance Quartey et al. (2017) 
asserted that inspite of the tremendous contributions offer by SMEs, number of challenges continues to limit SMEs growth and expansion strive citing lack of formalization and credit access as instances. Other previous researchers (Ayyagari et al., 2011; WBG, 2015; Appiah, et al., 2018) have equally reported on various credit constraints confronting SMEs investments strive. Competition has also been widely reported (Bouazza et al., 2015; Quartey et al., 2017; Appiah, et al. 2018), entrepreneurial capabilities had equally received research attention (Kazimoto, 2014; Abood et al., 2014, Bouazza et al., 2015), corruption among regulators poses serious investment challenge (Abood et al., 2014; Bouazza et al., 2015) and inadequate institutional support (Bouazza et al., 2015; Appiah et al., 2018) and more recently. For instance, Appiah et al. (2018) avowed that policy environment has the antidote to drastically reduce the plight of SMEs appropriately managed. However, ineffective policy environment is an indication that SMEs challenges will continue to exacerbate.

The researchers suggest that the various arms of government vis-executive, judiciary and legislative are required to strengthen and expedite the provisions in the local content policy including; local capabilities, local environmental, local polices and local infrastructure to enhance SMEs participation in the Ghanaian oil and gas sector. Media blitz could also be harnessed to augment policy awareness among SMEs. This study was limited to only Ghanaian SMEs. Therefore replication of this study is strongly encouraged among large scale corporation in futures. Moreover, the study deployed logit model with a binary outcome. We suggest that other models be employed to ascertain determinants of SMEs investment in the oil and gas industry.

\section{ACKNOWLEDGMENTS}

"This research received no specific grant from any funding agency in the public, commercial, or notfor-profit sectors."

\section{REFERENCES}

Abdullah, H. (2009). Major challenges to the effective management of human resource training and development activities. Journal of International Social Research, 2(8), 11-25.

Abood, N., Aboyasin, N. A., \& Ajloni, M. I. (2014). Impact of the Entrepreneurial Attributes on Business Performance in a Sample of Jordanian Institutions. International Journal of Professional Management, 9(1).

Abor, J., \& Quartey, P. (2010). Issues in SME Development in Ghana and South Africa. International Research Journal of Finance and Economics, 39, 218-28.

Acheampong, I. K. (2010). The Dutch Disease in the Context of Ghana's Oil Find: The Plausible Effects on the Economy of Ghana, A paper presented by Prof. I. K. Acheampong, at the Seminar Organised by Department of Economics, University of Cape Coast, 3rd March, 2010.

Ackah, J., \& Vuvor, S. (2011). The Challenges faced by Small \& Medium Enterprises (SMEs) in Obtaining Credit in Ghana. Master's Thesis in Business Administration, MBA program.

Adnan, Z., Abdullah, H.S \& Ahmad, J. (2011). Direct Influence of human resource management practices on financial performance in Malaysian R\&D companies. World Review of Business Research, 1(1), 61-77.

Agwu, O. M. \& Emeti, I. C. (2014). Issues, challenges and prospects of small and medium scale enterprises (SMEs) in Port-Harcourt city, Nigeria. European Journal of Sustainable Development, 3, 1, 101-114.

Amoako-Tuffour, J., \& M. Ghanney (2013) 'Ghana’s Petroleum Revenue Management Law: A Social Contract for Good Economic Governance and Possible Challenges'. In K. Appiah- Adu (ed.), Governance of the PetroleumSector in an Emerging Developing Economy. Farnham: Gower Publishing.

Appiah, K. M., Possumah, B. T., Ahmat, N., \& Sanusi, N. A. (2018). External Environment and SMEs Investment in The Ghanaian Oil and Gas Sector. Economics and Sociology, 11(1), 124-138. doi:10.14254/2071-789X.2018/11-1/8

Arthur, M. (2015). The constraint in credit accessibility among the SME's in Ghana. a case of selected businesses in the Kumasi metropolis. Kwame Nkrumah University of Science and technology. 
Asare, O. A. (2014). Challenges affecting SME's growth Ghana. OID A International Journal of Sustainable Development, 07 ; 06, 24-28.

Ayyagari, M., Demirgüç-Kunt, A., \& Maksimovic, V. (2011). Small vs. Young Firms Across The World - Contribution to Employment, Job Creation, and Growth. Policy Research Working Paper 5631 (The World Bank Development Research Group).

Avevor, E.E. (2016). Challenges faced by SME's when accessing fund from financial institutions in Ghana. University of Applied Sciences.

Bawumia, \& Halland (2017). Oil discovery and macroeconomic management. The recent Ghanaian experience. Policy Research Working Paper, World Bank Group,

Beaver, G., \& Hutchings, K. (2005). Training and developing an age diverse workforce in SMEs: The need for a strategic approach. Education + Training, I(8/9), 592-604.

Bouazza, B. A., Ardjouman, D., \& Abada, O. (2015). Establishing the factors affecting the growth of small and medium-sized enterprises in Algeria. American International Journal of Social Science, 4(2).

Cant, C.M., \& Wiid, J.A. (2013). Establishing the Challenges Affecting South African SMEs. International Business \& Economics Research Journal, 12(6).

Chandler G.N., \& McEvoy, G.M. (2000). Human resource management, total quality management and firm performance in small and medium sized enterprises. Entrepreneurship theory and practice, 25(1), 43-57.

Chimucheka, T., \& Mandipaka, F. (2015). Challenges faced by small, medium and micro enterprises in the Nkonkobe Municipality. The International Business \& Economics Research Journal (Online), 14(2), 309.

Chinonso, K. O. \& Zhen, T. (2016). The influence of entrepreneurial characteristics on small and medium-sized enterprise accessibility to debt finance in Nigeria. International Journal of Managerial Studies and Research, 4(10), 8392.

Neelufer, A., \& Al Amri, S. (2014). Challenges and barriers encountered by the SMEs owners in Muscat Blossom Christina. International Journal of Small Business and Entrepreneurship Research, 2(3), 1-13.

Chopra, S., Meindl, P., \& Kalra, V. (2007). Supply chain management: strategy, planning and operation. New Delhi: Dorling Kindersley.

Cox, D. R. (1958). The regression analysis of binary sequences. Journal of the Royal Statistical Society,

Dalberg, (2011). Report on Support to SMEs in Developing Countries Through Financial Intermediaries. SME Briefing Paper, EIB Draft Version (Geneva: European Investment Bank).

Emezie, S. (2017). Prospects and challenges of SMEs in $21^{\text {st }}$ century Africa. University of Applied Sciences.

Eniola, A. A., \& Entebang, H. (2015). SME firm performance-financial innovation and challenges. Procedia-Social and Behavioral Sciences, 195, 334-342.

Eton, M., Mwirumubi, R., \& Edaku, C. (2017). Challenges Faced by Development Partners in Supporting the Growth and Development of Commercial Enterprises in Lira District, Northern Uganda. Journal of Education and Practice, 8(11), 88-94.

Farsi, J. Y., \& Toghraee, M. T. (2014). Identification the main challenges of small and medium sized enterprises in exploiting of innovative opportunities (Case study: Iran SMEs). Journal of Global Entrepreneurship Research, 4(1), 4.

Fouad, M. A. A. (2013). Factors affecting the performance of small and medium enterprises (SMEs) in the manufacturing sector of Cairo, Egypt. International Journal of business and management studies, 5(2), 157-166.

Fox, W., \& Bayat, M. S. (2008). A guide to managing research. Juta and Company Ltd.

Fuseini, G. (2015). Small and medium-sized enterprises' (SME's) access to credit in Ghana: determinants and challenges. University Of Ghana.

Galli, E., Mascia, V.D., \& Rossi, P.S.S. (2017). Does corruption affect access to bank credit for micro and small businesses? Evidence from European MSMES.

Gbetnkom, D. (2012). Corruption and small and medium-sized enterprise growth in Cameroon: Kigali, Rwanda.

Ghana statistical service (2016). Statistics for development and training. Revised 2015 annual gross domestic product.

Ghatak, S. (2010). Micro, Small and Medium Enterprises (MSMEs) in India: An Appraisal. www.legalpundits.com/Content folder/SMEArti150610.pdf

Goldratt, E. M., \& Cox, J. (1984). The Goal, Croton-on-Hudson. NY: North River Press Inc.

GSS. (2000). Helping you make informed decisions. 
Gumel, B. I. (2017). Critical Challenges Facing Small Business Enterprises in Nigeria: A Literature Review. International Journal of Scientific and Engineering Research, 8(8), 796-808.

Hamdani, J. \& Wirawan, C. (2012). Open innovation implementation to sustain Indonesian SMEs. Procedia Economics and Finance, 4, 223-233

Hamisi, S. (2010). Challenges and opportunities of Tanzaniaes SMEs in adapting supply chain management. African Journal of Business Management, 5(4) 1266-1276.

Haron, R., \& Ibrahim, K. (2016). Islamic Financing in Mitigating Access to Financing Problems of SMEs in Malaysia: A Survey Analysis. Intellectual Discourse, 24, 387-408.

Hutchings, J. A. (2005). Life history consequences of overexploitation to population recovery in Northwest Atlantic cod (Gadus morhua). Canadian Journal of Fisheries and Aquatic Sciences, 62(4), 824-832.

Islam, M. A., Khan, M. A., Obaidullah, A. Z. M., \& Alam, M. S. (2011). Effect of entrepreneur and firm characteristics on the business success of small and medium enterprises (SMEs) in Bangladesh. International Journal of Business and Management, 6(3), 289-299.

ILO (2015). World employment social outlook. Trends.

Islam, M. Z., \& Siengthai, S. (2010). Human resource management practices and firm performance improvement in Dhaka Export Processing Zone (DEPZ). Research and Practice in Human Resource Management, 18(1), 60-77.

Kamunge, M. S., Njeru, A. \& Tirimba, O. I. (2014). Factors affecting the performance of small and macro enterprises in Limuru town market of Kiambu County. International Journal of Scientific and Research Publications, 4(12), 1-20.

Kanu, A. M. (2015). The effect of corruption on small and medium enterprises: Perspective from a developing country. International Journal of S mall Business and Entrepreneurship Research, 3(3), 12-27.

Kazimoto, P. (2014). Assessment of challenges facing small and medium enterprises towards international marketing standards: a case study of Arusha region Tanzania.

Alasmari, K. A. (2012). Cleaning up dirty money: The illegal narcotics trade and money laundering. Economics \& Sociology, 5(2A), 139-148.

Kibret, G.B., Lalisho, A.A., Rokandla, R.V., \& Belayneh, S.E. (2015). Opportunities and Challenges of Small Business Enterprises in Gedeo Zone- Ethiopia: From Policy, Regulatory and Institutional Perspectives. Asia Pacific Journal of Applied Finance: Vol. IV Issue 2.

Koudelková, P., \& Senichev, V. (2015). Mix Research Approach towards Corruption-Experts' Perception: Challenges and Limitations. Procedia-Social and Behavioral Sciences, 175, 39-47.

Lampadarios, E. (2016). Critical success factors for SMEs: an empirical study in the UK chemical distribution industry. International Journal of Business and Management, 11(7), 1-9.

Lyimo, E.S. (2014). Challenges and prospects faced by small and medium enterprises in accessing credit facility: a case of agricultural inputs sellers and distributors in Arusha city.

McGrath, H., \& O'Toole, T. (2011). Challenges in implementing the markets-as-networks approach to marketing for SMEs. Irish Marketing Review, 21(1/2), 58.

Ministry of energy Ghana. (2010). Oil and Gas: Helping entities connect to the world's fastest growing economy. Investment Opportunities

Mohamad, M. R., Sidek, S., Ghee, W. Y., Abdullah, A. R., Ismail, N. A., \& Mustapha, N. (2015). Financial access for starting a business: Evidence of internal and external financial sources, and performance of Malaysian SMEs. Journal of Entrepreneurship and Business, 3(1), 1-16.

Krejcie, R. V., \& Morgan, D. W. (1970). Determining sample size for research activities. Educational and psychological measurement, 30(3), 607-610.

Morone, P., \& Testa, G. (2005). What Makes Small and Medium Enterprises Competitive: An investigation into the Italian manufacturing sector.

Muriithi, S. M. (2015). The relationship between leadership and organisational effectiveness. Unpublished Doctoral thesis. Grahamstown: Rhodes University.

Nyan'au, F. O. (2013). Challenges Facing Micro and Small Enterprises in Inventory Management in Kisii Town, Kenya. IOSR Journal of Business and Management, 13(5), 20-29.

Ocloo, C. E., Akaba, S., \& Worwui-Brown, D. K. (2014). Globalization and competitiveness: Challenges of small and medium enterprises (SMEs) in Accra, Ghana. International Journal of Business and Social Science, 5(4). 
Arokiasamy, L., \& Ismail, M. (2009). The background and challenges faced by the small medium enterprises. A human resource development perspective. International Journal of Business and Management, 4(10), 95.

Orinda, R. (2014). A research project submitted in partial fulfillment of the requirement for the award of master of business administration, University of Nairobi.

Osei, B., Baah-Nuakoh, A., Tutu, K., Sowa, N. (1993). Impact of structural adjustment on small-scale enterprises in Ghana. In: Helmsing, A., Kolstee, T. (Eds.). Small Enterprise and Changing Policies: Structural Adjustment, Financial Policy and Assistance Programmes in Africa. IT Publications, London

Oshikoya, T. W., \& Hussain, M. N. (2007). Information Technology and the Challenge of Economic Development in African E-Markets Information and Economic Development. In A. Opoku-Mensah \& M. A. M. Salih (Eds.), Economic Commission for Africa (pp. 43-76). Norwich, UK. University of East Anglia.

Oyelana, A. A. \& Smith, W. (2015). An investigation into challenges as well as means to overcome challenges facing small and medium enterprises (SMEs) in South Africa. Journal of Economics, 6(2), 177-188.

Pepra, C. (2016). Challenges SME's face in acquiring loans from banks. A Comparative Study between Finland and Ghana Peprah, C. (2016). Challenges SMEs face in acquiring loans from banks. Centria University of Applied Sciences

Prempeh, B.K. (2015). Problems of financing SME's in Ghana: A case study of the Sunyani municipality. Journal of The International Association of Advanced Technology and Science, 16.

Quartey, P., Turkson, E., Abor, J. Y., Iddrisu, A. M. (2017). Financing the growth of SMEs in Africa: What are the constraints to SME financing within ECOWAS? Review of Development Finance, 7, 18-28.

Rahman, N. A., Yaacob, Z., \& Radzi, R. M. (2016). The Challenges Among Malaysian SME: A Theoretical Perspective. World, 6(3), 124-132.

Rogger, R.B. (2002). "A Language for Interactive Audio Applications." Citeseer.

Rune, A. (2011). Exploring the business case for western SMEs to counter involvement in administrative corruption in developing countries. Copenhagen Business School.

Rupeika-Apoga, R. (2014). Financing in SMEs: case of the Baltic States. Procedia-Social and Behavioral Sciences, 150, 116125.

Ruskov, P., Haralampiev, K., \& Georgiev, L. (2012). Online Investigation of SMEs Competitive Advantage. $10^{\text {th }}$ International Conference on Management, Enterprise and Benchmarking

Saunders, M., Lewis, P., \& Thornhill, A. (2012). Research Methods for Business Students 6th edition, Pearson Education Limited

Sidika, I. (2012). Conceptual framework of factors affecting SME development: Mediating factors on the relationship of entrepreneur traits and SME performance. Proceedings from ICSMED 2012: International Conference on Small and Medium Enterprises Development. Procedia Economics and Finance, 4, 373 -383.

Sitharam, S., \& Hoque, M. (2016). Factors affecting the performance of small and medium enterprises in KwaZuluNatal, South Africa. Problems And Perspectives I n Management, 14(2), 277-288.

Soini, E., \& Veseli, L. (2011). Factors influencing SME's growth in Kosovo. International business management.

Soon, T. T. (2006). Malaysian SMEs-The External and Internal Challenges.

Sulemenova, G., Sadvokassova, A., Rakisheva, B., \& Nurmaganbetov, A. (2018). SMe's development and corruption. Business: Theory and Practice, 19, 1-8.

Taghizadeh-Hesary, F. (2016). Japan's energy developments and TPP: Cases on petroleum, Natural Gas and Coal. Taiwan Research Institute.

Tsalikis, J., \& Peralta, A. (2014). Priming effects on business ethical decision making. International journal of strategic innovative marketing, 1(1), 1-8.

Waked, B. (2016). Access to Finance by Saudi SMEs: Constraints and the Impact on their Performance. College of Business.

W Wang, Y. (2016). What are the biggest obstacles to growth of SMEs in developing countries?-An empirical evidence from an enterprise survey. Borsa Istanbul Review, 16(3), 167-176.

WBG (2015). Global economic development at Brookings. Working paper 92.

Chaplin, M. H., \& Westwood, M. N. (1972). method for estimating the yields of sweet cherry. HortScience, 7(5), 508 509. 
Yoshino, N., \& Taghizadeh-Hesary, F. (2016). Major Challenges Facing Small and Medium-sized Enterprises in Asia and Solutions for Mitigating Them. ADBI Working Paper 564. Tokyo: Asian Development Bank Institute. Available: http://www.adb.org/publications/major-challenges-facing-small-and-medium-sized-enterprises-asiaand-solutions/

Zidana, R. (2014). Small and Medium Enterprises (SMEs) financing and economic growth in Malawi: Measuring the impact between 1981 and 2014. Lilongwe, Malawi.

Zikmund, W. G., Babin, J., Carr, J., \& Griffin, M. (2012). Business Research Methods: with Qualtrics Printed Access Card. Cengage Learning. 